\title{
Pengaruh Konsentrasi Pupuk Organik Cair Urin Domba terhadap Tanaman Pakcoy ( Brassica rapa L.) dengan Sistem Sumbu
}

\author{
Suhenda, Reni Nurjasmi, dan Ayu Vandira Candra Kusuma \\ Program Studi Agroteknologi Fakultas Pertanian Universitas Respati Indonesia Jakarta \\ Email: suhenda642@gmail.com
}

\begin{abstract}
ABSTRAK
Pakcoy merupakan salah satu jenis tanaman sayuran daun yang memiliki nilai ekonomi tinggi, bergizi, dan disukai banyak orang. Salah satu sistem budidaya tanaman pakcoy yang dapat digunakan adalah sistem sumbu. Sistem ini merupakan teknologi hidroponik yang paling sederhana dan murah. Tujuan penelitian adalah mengetahui pengaruh penggunaan konsentrasi pupuk organik cair urin domba terhadap tanaman pakcoy serta konsentrasi yang memberikan pertumbuhan dan hasil tanaman pakcoy yang terbaik. Penelitian dilaksanakan di Balai Penyuluhan Pertanian Kecamatan Karangbahagia Kabupaten Bekasi menggunakan Rancangan Acak Kelompok Non Faktorial dengan 5 perlakuan dan 4 ulangan. Semua perlakuan diberikan larutan $A B$ Mix $50 \%$ dan penggunaan pupuk organik cair urin domba $0 \mathrm{ml} /$ liter air, $5 \mathrm{ml} /$ liter air, $10 \mathrm{ml} /$ liter air, $15 \mathrm{ml} /$ liter air, dan $20 \mathrm{ml} /$ liter air. Parameter penelitian adalah tinggi tanaman, jumlah daun per tanaman, berat segar tanaman, dan berat segar tajuk tanaman. Data dianalisis menggunakan uji $\mathrm{F}$, apabila signifikan dilanjutkan dengan uji DMRT $5 \%$. Berdasarkan hasil penelitian, konsentrasi pupuk organik cair urin domba berpengaruh nyata terhadap tanaman pakcoy pada sistem sumbu. Pada 28 Hari Setelah Tanam (HST) konsentrasi urin domba $20 \mathrm{ml} /$ liter air menghasilkan tinggi tanaman dan jumlah daun tertinggi, masing-masing $26,13 \mathrm{~cm}$ dan 17,25 helai berbeda nyata dengan perlakuan tanpa urin domba namun berbeda tidak nyata dengan perlakuan urin domba lainnya. Konsentrasi urin domba $20 \mathrm{ml} /$ liter air menghasilkan bobot basah tanaman tertinggi yaitu 120,11 gram dan berbeda nyata dengan perlakuan lainnya kecuali dengan perlakuan konsentrasi urin domba $10 \mathrm{ml} /$ liter air serta bobot tajuk tanaman tertinggi yaitu 26,13 gram dan berbeda nyata dengan perlakuan lainnya.
\end{abstract}

Kata Kunci: Pupuk Organik Cair, Urin Domba, Pakcoy, Sistem Sumbu

\begin{abstract}
Pakcoy is a type of leaf vegetable that has high economic value, is nutritious, and is liked by many people. One of the pakcoy cultivation systems that can be used is the axis system. This system is the simplest and cheapest hydroponic technology. The purpose of this study was to determine the effect of using the concentration of liquid organic fertilizer in sheep's urine on pakcoy plants and the concentration that gave the best growth and yield of pakcoy plants. The research was carried out at the Agricultural Extension Center, Karang Bahagia Subdistrict, Bekasi Regency using a Non-Factoral Randomized Block Design with 5 treatments and 4 replications. All treatments were given a 50\% AB Mix solution and the use of liquid organic fertilizer sheep urine 0 $\mathrm{ml} /$ liter of water, $5 \mathrm{ml} /$ liter of water, $10 \mathrm{ml} /$ liter of water, $15 \mathrm{ml} /$ liter of water, and $20 \mathrm{ml} /$ liter of water. The research parameters were plant height, number of leaves per plant, fresh weight of plant, and fresh weight of plant crown. The data were analyzed using the $F$ test, if significant, it was continued with the DMRT $5 \%$ test. Based on the results of the study, the concentration of liquid organic fertilizer in sheep urine had a significant effect on pakcoy plants on the axis system. At 28 Days After Planting (DAT) the concentration of sheep urine $20 \mathrm{ml} /$ liter of water resulted in the highest plant height and number of leaves, $26.13 \mathrm{~cm}$ and 17.25 strands, respectively, significantly different from the treatment without sheep urine but not significantly different from the urine treatment. other sheep. The concentration of sheep urine $20 \mathrm{ml} /$ liter of water resulted
\end{abstract}


in the highest plant wet weight of 120.11 grams and significantly different from other treatments except for the treatment of sheep urine concentration of $10 \mathrm{ml} /$ liter of water and the highest plant crown weight of 26.13 grams and significantly different from the treatment. other.

Keywords: Liquid Organic Fertilizer, Sheep Urine, Pakcoy, Axis System

\section{PENDAHULUAN}

Pakcoy merupakan salah satu jenis sayuran hijau yang masih satu keluarga dengan sawi. Pakcoy sering disebut sawi sendok karena bentuknya yang menyerupai sendok. Pakcoy juga sering disebut dengan sawi manis atau sawi daging karena pangkalnya yang lemut dan tebal seperti daging. Tanaman ini berasal dari China dan biasanya digunakan untuk bahan sup atau bahan penghias makanan. Pakcoy mengandung protein, vitamin $A, B, B 2, B 6, C$, E dan $\mathrm{K}$, serat, kalsium, magnesium, fosfor, tembaga dan zat besi. Kandungan yang dimiliki pakcoy dapat membantu proses pembekuan darah, mencegah penyakit jantung, stroke sehingga dapat membantu kesehatan [1].

Pemenuhan kebutuhan sayuran yang sehat dan terbebas dari polutan dewasa ini merupakan masalah yang sangat penting bagi masyarakat perkotaan. Pada saat yang bersamaan adanya perubahan proporsi urban rural menjadi urban modern menyebabkan pertumbuhan pembanguan properti yang masif, dan dampaknya terjadi konversi lahan pertanian ke non pertanian dengan cepat. Kondisi ini jelas akan berpengaruh terhadap ketersediaan bahan pangan yang pada gilirannya mempengaruhi ketahanan pangan di masa yang akan datang. Salah satu solusi untuk mengatasi permasalahan tersebut ialah dengan mengembangkan sistem budidaya hidroponik.

Hidroponik secara etimologi berasal dari kata hydro yang berarti "air" dan ponos yang berarti "mengerjakan". Hidroponik dimaknai sebagai cara budidaya tanaman dengan menggunakan medium air [2]. Hidroponik merupakan salah satu sistem budidaya masa depan, karena dapat diusahakan di berbagai tempat, baik di lahan terbuka maupun tertutup, pada luas lahan yang sempit, tidak mengenal musim, baik musim hujan maupun kemarau, dan produktivitasnya lebih tinggi dibandingkan dengan sistem konvensional. Teknologi hidroponik merupakan inovasi dalam budidya tanaman tanpa media tanah namun memanfaatkan nutrisi, air, serta bahan porous sebagai media tanam [3]. Teknologi hidroponik juga dapat mentolerir kondisi lingkungan yang tidak ideal bagi tanaman [4].

Hal terpenting dalam sistem budidaya dengan hidroponik ialah kandungan hara dalam air yang diberikan terus-menerus sebagai nutrisi. Nutrisi tanaman terlarut dalam ar yang digunakan 
dalam hidroponik sebagan besar adalah anorganik dalam bentuk ion. Larutan nutrisi yang paling mendasar adalah $\mathrm{N}, \mathrm{P}, \mathrm{K}, \mathrm{Ca}, \mathrm{Mg}$ dan $S$ yang juga dilengkapi dengan mikronutrien [5].

Nutrisi untuk hidroponik yang telah dikenal ialah $A B$ Mix, namun harga $A B$ Mix relatif mahal, sehingga untuk kegiatan usaha skala besar dibutuhkan bahan alternatif pengganti $A B$ Mix atau megurangi dosis konsentrasi $A B$ Mix dengan cara mengkombinasikan dengan Pupuk Organik Cair (POC) yang harganya lebih murah [6]. Penggunaan $A B$ Mix memerlukan biaya yang relatif tinggi sehingga masyarakat umum memandang bahwa teknologi secara hidroponik memiliki nilai ekonomi yang cukup besar dalam perawatan dan penyediaan pupuk [7]. Oleh karena itu, perlu dicari alternatif subtitusi AB Mix dengan POC yang relatif murah dan mudah dijangkau dan bila harus membuat sendiri bahan mudah diperoleh dan cara pengerjaanmya mudah. Penelitian lain untuk mendapatkan alternatif nutrisi subtitusi $A B$ Mix dalam sistem sumbu telah dilakukan antara lain penggunaan POC bonggol pisang dalam budidaya tanaman sawi [8].

Urin sapi menghandung hormon IAA (indole acetate acid) yang berpengaruh terhadap pertumbuhan tanaman [9]. Urin kambing mengandung $\mathrm{N}, \mathrm{K}$ dan hormon pertumbuhan tanaman [10] sedangkan urin domba mengandung $1,35 \% \mathrm{~N}, 0,05 \% \mathrm{P}$ dan
2,10 \% K [11 ]. Dilihat dari kandungannya, maka urin domba mengandung nutrisi yang lebih baik dari pada urin sapi yang hanya mengandung $\mathrm{N} 15 \% \mathrm{~N}, 0,5 \% \mathrm{P}$, dan $0,5 \% \mathrm{~K}$. Penelitian untuk mensibtitusi $A B$ Mix dengan biourin telah banyak dilakukan, namun pada umumnya menggunakan urin sapi dan urin kambing, sementara urin domba belum banyak dilakukan penelitian, terutama pada sistem hidroponik dengan sistem sumbu. Sistem sumbu merupakan salah satu sistem yang paling sederhana dari semua sistem hidroponik karena tidak memiliki bagian yang bergerak sehingga tidak menggunakan pompa atau listrik. Sistem ini termasuk ke dalam sistem pasif karena tanaman tidak menyentuh secara langsung dengan air. Tanaman memperoleh nutrisi melalui penyerapan unsur nutrisi oleh akar melalui sumbu. Sistem ini banyak digunakan karena selain sederhana juga murah [12]. Tujuan penelitian ini adalah mengetahui pengaruh $\mathrm{POC}$ urin domba terhadap pertumbuhan dan hasil tanaman pakcoy yang dibudidayakan dengan sistem sumbu.

\section{METODE}

\section{Waktu dan Tempat}

Penelitian dilaksanakan di Balai Penyuluh Pertanian Kecamatan Karangbahagia Kabupaten Bekasi Jawa Barat pada Maret sampai dengan Agustus 2021. 


\section{Alat dan Bahan}

Bahan yang digunakan yaitu rookwool, benih pakcoy, POC urin domba, dan nutrisi $A B$ mix. Alat yang digunakan yaitu kain flanel, netpot, bak penampung nutrisi, bak persemaian, pompa air, TDS meter, $\mathrm{pH}$ Meter, dan timbangan digital.

\section{Rancangan Penelitian}

Penelitian menggunakan Rancangan

Acak Kelompok Non Faktorial yaitu konsentrasi POC urin domba yang terdiri atas 5 perlakuan yaitu $0 \mathrm{ml} /$ liter, 5 $\mathrm{ml} /$ liter10 $\mathrm{ml} /$ liter15 $\mathrm{ml} /$ liter20 $\mathrm{ml} /$ liter. Masing-masing perlakuan diulang sebanyak 4 ulangan, sehingga terdapat 20 unit percobaan

\section{Cara Kerja}

Hidroponik sistem sumbu dibuat dengan mengunakan bak. Bak tersebut digunakan sebagai tempat nutrisi dan bak ditutup dengan mengunakan penutup fiber. Pengisian larutan dilakukan dengan cara melakukan pengecekan dan pengamatan setiap pagi dan sore hari. Hal ini dilakukan dengan cara mengukur penurunan atau pengurangan tinggi air larutan nutrisi yang dibutuhkan tanaman sebagai evapotranspirasi tanaman. Kemudian larutan nutrisi yang berkurang dikembalikan pada kondisi awal sebelum terjadi evaotranspirasi dengan larutan nutrisi. Sebelum dilakukan penambahan larutan nutrisi, terlebih dahulu dilakukan pengukuran penurunan air yang terlihat pada bak.

Benih pakcoy direndam di dalam air hangat selama 1 jam untuk melembabkan kulit benih, sehingga pori-pori kulit dan benih cepat berkecambah, Media semai dengan mengunakan rokwoll yang telah di potong dadu serta sudah dibasahi. Bibit tanaman Pakcoy yang telah berumur 12 hari atau sudah berdaun 4 dipindah ke instalasi hidroponik sistem sumbu. Konsentrasi POC urin domba pada setiap instalasi disesuaikan dengan perlakuan. Kegiatan pemeliharaan ini meliputi penyulaman tanaman yang mati. Penyulaman dilakukan sebelum umur tanaman berumur $14 \mathrm{HS}, \mathrm{pH}$ air jumlah $\mathrm{POC}$ urin domba selalu dikontrol demikian pula dengan keberadaan organisme pengganggu tanaman yang mengganggu tanaman pakcoy.

Proses pemanenan dilakukan ketika tanaman pakcoy berumur 40-45 hari setelah tanam dan dipanen pada pagi hari. Selama proses panen sebaiknya tanaman pakcoy harus terhindar dari sinar matahari langsung, hal ini dilakukan agar hasil panen tidak mudah layu.

\section{Variabel Penelitian}

Variabel penelitian yang diamati adalah tinggi tanaman dan jumlah daun diukur satu minggu sekali serta bobot segar 
tanaman dan bobot segar tajuk tanaman pakcoy yang diukur setelah panen.

\section{Analisis Data}

Data Hasil pengamatan diuji dengan analisa sidik ragam, bila sidik ragam berbeda nyata $\quad(F$ hitung $>F$ tabel 0,05 ) atau berbeda sangat nyata ( $F$ hitung $>F$ tabel 0,01 ). Maka untuk membandingkan data rata-rata taraf perlakuan, dilakukan uji lanjut dengan uji t taraf $5 \%$ sedangkan bila sidik ragam berbeda tidak nyata ( $\mathrm{F}$ hitung $\leq$ F tabel 0,05 ) maka tidak dilakukan uji lanjutan. Analisis data menggunakan program SPSS.

\section{HASIL DAN PEMBAHASAN}

Pengaruh Pupuk Organik Cair Urin Domba terhadap Tinggi Tanaman Pakcoy

Hasil pengamatan tinggi tanaman umur 7 Hari Setelah Tanam (HST), 14 HST, 21 HST dan 28 HST disajikan pada Tabel 1. Tabel 1 menunjukkan bahwa terjadi peningkatan tinggi tanaman pakcoy dari 7 HST sampai 28 HST. Secara umum, terjadi pula peningkatan tinggi tanaman sejalan dengan meningkatnya konsentrasi urin domba yang diberikan. Pada 21 HST dan 28 HST, dapat diketahui bahwa perlakuan urin domba menghasilkan tinggi tanaman yang lebih baik dan berbeda nyata dengan perlakuan tanpa urin domba.

Tabel 1. Pengaruh konsentrasi pupuk organik cair urin domba terhadap tinggi tanaman Pakcoy

\begin{tabular}{|c|c|c|c|c|}
\hline \multirow[t]{2}{*}{ Perlakuan } & \multicolumn{4}{|c|}{ Rata-rata Tinggi Tanaman (cm) } \\
\hline & $7 \mathrm{HST}$ & $14 \mathrm{HST}$ & $21 \mathrm{HST}$ & $28 \mathrm{HST}$ \\
\hline $0 \mathrm{ml} / \mathrm{liter}$ air & 4,18 a & 7,67 a & $12,05 \quad a$ & $18,20 \quad a$ \\
\hline $5 \mathrm{ml} /$ liter air & 4,22 a & 7,69 a & $15,14 \quad b$ & $21,47 \quad b$ \\
\hline $10 \mathrm{ml} /$ liter air & 4,35 a & $9,85 a b$ & $15,53 \quad b$ & $22,00 \quad b$ \\
\hline $15 \mathrm{ml} / \mathrm{liter}$ air & 4,48 a & $8,05 a b$ & 17,15 bc & $19,52 b$ \\
\hline $20 \mathrm{ml} / \mathrm{liter}$ air & 5.52 a & $10,11 \mathrm{c}$ & 19,05 & $26,13 b$ \\
\hline
\end{tabular}

Keterangan : angka rata-rata yang diikuti hurup yang sama tidak berbeda nyata menurut Uji DMRT taraf kesalahan $5 \%$

Perlakuan yang menghasilkan tinggi tanaman terbaik adalah konsentrasi urin domba $20 \mathrm{ml} /$ liter air namun berbeda tidak nyata dengan perlakukan urin domba lainnya kecuali pada 14 HST yang berbeda nyata dengan perlakuan lainnya. Fase vegetatif berhubungan dengan 3 (tiga) proses penting yaitu (a) pembelahan sel, (b) pemanjangan sel, dan (c) diferensiasi sel. Pada proses pertumbuhan diperlukan (a) pemberian air yang banyak, (b) adanya hormon tertentu yang memungkinkan 
dinding-dinding sel merentang, dan (c) adanya gula.

Pengaruh Pupuk Organik Cair Urin Domba terhadap Jumlah Daun Tanaman Pakcoy hanya mampu menyediakan unsur hara namun juga mampu mengaktifkan mikroorganisme penambat $\mathrm{N}$ dan perombak bahan organik, juga berperan dalam meningkatkan tekanan osmotik sel tanaman, berperan dalam sejumlah katalitik untuk aktif dalam berbagai reaksi enzim di dalam sel dan berfungsi antagonetik dan keseimbangan [13] . Urin ternak domba bukan hanya mengandung unsur $\mathrm{N}, \mathrm{P}$, dan $\mathrm{K}$ yang tinggi namun juga mengandung hormon-hormon yang sangat dibutuhkan untuk pertumbuhan dan perkembangan tanaman [14]. Proses pembelahan sel akan berjalan dengan cepat karena adanya ketersediaan nitrogen yang cukup dan nitrogen berperan dalam merangsang pertumbuhan batang yang memacu pertumbuhan tinggi tanaman.
Hasil analisis data pengamatan jumlah daun per tanaman mulai dari pengamatan 7 HST, 14 HST, 21 HST dan 28 HST disajikan pada Tabel 2. Tabel 2 menunjukkan bahwa terjadi peningkatan jumlah daun tanaman pakcoy dari 7 HST sampai 28 HST. Secara umum, terjadi pula peningkatan jumlah daun tanaman sejalan dengan meningkatnya konsentrasi urin domba yang diberikan. Pada 14 HST, 21 HST dan 28 HST, dapat diketahui bahwa perlakuan urin domba menghasilkan jumlah tanaman yang lebih baik dan berbeda nyata dengan perlakuan tanpa urin domba. Pada 28 HST, perlakuan konsentrasi urin domba $20 \mathrm{ml} /$ liter air menghasilkan jumlah daun paling tinggi namun berbeda tidak nyata dengan perlakuan lainnya.

Tabel 2. Pengaruh konsentrasi pupuk organik cair urin domba terhadap jumlah daun tanaman pakcoy

\begin{tabular}{|c|c|c|c|c|c|c|}
\hline \multirow{3}{*}{$\begin{array}{l}\text { Perlakuan } \\
0 \text { ml/liter air }\end{array}$} & \multicolumn{6}{|c|}{ Rata-rata Jumlah Daun per Tanaman } \\
\hline & \multirow{2}{*}{$\begin{array}{l}7 \mathrm{HST} \\
4,00 \mathrm{a}\end{array}$} & \multirow{2}{*}{$\begin{array}{l}14 \text { HST } \\
6,15 \text { a }\end{array}$} & \multicolumn{2}{|c|}{$21 \mathrm{HST}$} & \multicolumn{2}{|c|}{$28 \mathrm{HST}$} \\
\hline & & & 9.36 & $\mathrm{a}$ & 13,00 & $a$ \\
\hline $5 \mathrm{ml} /$ liter air & $4,68 \mathrm{a}$ & $6,67 b$ & 10,22 & $b$ & 16,00 & b \\
\hline $10 \mathrm{ml} /$ liter air & $4,75 \mathrm{a}$ & $7,05 \quad b$ & 11,05 & C & 17,00 & b \\
\hline $15 \mathrm{ml} /$ liter air & $5,10 \mathrm{a}$ & $9,13 \mathrm{c}$ & 11,56 & c & 17,25 & $b$ \\
\hline $20 \mathrm{ml} /$ liter air & $5,75 \mathrm{a}$ & $10,15 d$ & 14,15 & $d$ & 17,25 & $b$ \\
\hline
\end{tabular}

Keterangan : angka rata-rata yang diikuti hurup yang sama tidak berbeda nyata menurut Uji DMRT taraf kesalahan $5 \%$ 
Urin domba mengandung $\mathrm{N}$ yang cukup tinggi. Tanaman menjerap $\mathrm{N}$ dalam bentuk ammonium $\left(\mathrm{NH}_{4}\right)$. Ammonium mengikat karbon (C) membentuk asam glutamat, yang digunakan untuk menghasilkan asam amino. Asam amino bergabung dengan asam amino membentuk protein. Protein mengontrol pertumbuhan tanaman dengan aktivtas enzim. Tanaman yang cukup asupan $\mathrm{N}$ berwarna hijau dan pertumbuhannya normal, sedangkan yang kekurangan $\mathrm{N}$ pertumbuhannya kerdil, daun klorosis, pembentukan bunga atau buah tertunda sehingga produktivitas rendah [15]. Pupuk organik cair urin domba mengandung $\mathrm{N}$ yang cukup tinggi sehingga menyebabkan kandungan nitrogen dalam larutan hara pada air yang dialirkan melalui sumbu pada sistem sumbu akan meningkatkan serapan $\mathrm{N}$ oleh tanaman meningkat. Meningkatnya serapan N dapat menyebabkan kandungan klorofil tanaman menjadi lebih tinggi sehingga laju fotosintesis meningkat. Laju fotosintesis meningkat menyebabkan sintesis karbohidrat juga meningkat. Pembentukan karbohidrat yang disebabkan oleh laju fotosintesis akan meningkatkan pertumbuhan vegetatif tanaman termasuk pembentukan daun dan tinggi tanaman [16]. Pada fase vegetatif tanaman membutuhkan karbohidrat (gula) yang tinggi.

Pemberian $\mathrm{P}$ berpengaruh terhadap ketersediaan unsur $N$ [17]. Apabila $P$ yang dapat dijerap tanaman meningkat, maka $\mathrm{N}$ tersedia pun meningkat. Fosfor berperan dalam menyusun tubuh tanaman dan beberapa koenzim yang berperan dalam aktivitas metabolisme. Meningkatnya aktivitas metabolisme, bahan organik yang terbentuk cukup tersedia sehingga akan dihasilkan karbohidrat dan akan diubah menjadi organ-organ tanaman seperti akar, batang dan daun [18].

Pakcoy merupakan salah satu tanaman sayuran yang dikonsumsi bagian vegetatifnya, terutama daunnya. Tanaman pakcoy membutuhkan nitrogen yang cukup untuk menghasilkan pertumbuhan dan kualitas hasil yang baik [19]. Data penelitian menunjukan bahwa pada dosis $20 \mathrm{ml} /$ liter air urin domba menunjukan pertumbuhan terutama untuk parameter tinggi tanaman dan jumlah daun yang lebih tinggi dibandingkan perlakuan lainnya. Penelitian lain membuktikan bahwa pemberian $20 \mathrm{ml}$ biourin kambing dan 16 gr kascing pada tanaman pakcoy menghasilkan bobot segar dan bobot kering tertinggi [20].

\section{Pengaruh Pupuk Organik Cair Urin Domba} terhada Bobot Basah Tanaman

Pengamatan berat bobot basah per tanaman dilakukan saat panen. Hasil pengolahan data disajikan pada Tabel 3. Tabel 3 menunjukkan bahwa terjadi peningkatan bobot basah tanaman sejalan dengan meningkatnya konsentrasi urin 
domba yang diberikan. Perlakuan urin domba $20 \mathrm{ml} /$ liter air menghasilkan bobot basah tanaman yang lebih tinggi dan berbeda nyata dengan perlakuan tanpa urin domba namun berbeda tidak nyata dengan perlakuan $10 \mathrm{ml} /$ /iter air. Diduga karena $\mathrm{N}$,
$\mathrm{P}$, dan $\mathrm{K}$ yang tersedia dalam $\mathrm{POC}$ urin domba. Ketersediaan unsur hara akan meningkatkan laju fotosintesis dan berdampak terhadap ketersediaan asimilat yang dapat digunakan untuk pertumbuhan dan hasil tanaman pakcoy.

Tabel 3. Pengaruh Konsentrasi Pupuk Organik Cair Urin Domba terhadap Berat Basah Tanaman Pakcoy

\begin{tabular}{cr}
\hline Dosis Urin Domba & Bobot Basah Tanaman (gram) \\
\hline $0 \mathrm{ml} /$ liter air & 92,24 a \\
$5 \mathrm{ml} /$ liter air & 95,11 a \\
$10 \mathrm{ml} /$ liter air & $100,89 \mathrm{ab}$ \\
$15 \mathrm{ml} /$ liter air & $96,95 \mathrm{a}$ \\
$20 \mathrm{ml} /$ liter air & $120,11 \mathrm{~b}$
\end{tabular}

Keterangan : angka rata-rata yang diikuti hurup yang sama tidak berbeda nyata menurut Uji DMRT taraf kesalahan 5\%

Ketersediaan unsur hara berperan penting sebagai sumber energi sehingga tingkat kecukupan hara berperan dalam mempengaruhi biomassa dari suatu tanaman, sedangkan pemberian dosis kecil tidak memberikan pengaruh yang signifikan [21]. Berat basah tanaman dipengaruhi oleh kelembaban serta kadar air di dalam jaringan [22]. Kandungan air di dalam tanaman akan meningkat sejalan dengan peningkatan kandungan nitrogen sehingga dapat meningkatkan bobot berat basah suatu tanaman [23].

\section{Pengaruh Pupuk Organik Cair Urin domba Terhadap Bobot Tajuk Tanaman}

Pengamatan berat tajuk tanaman dilakukan saat panen. Hasil pengolahan data disajikan pada Tabel 4. Tabel 4 menunjukkan bahwa terjadi peningkatan bobot tajuk tanaman sejalan dengan meningkatnya konsentrasi urin domba yang diberikan. Perlakuan urin domba $20 \mathrm{ml} /$ liter air menghasilkan bobot basah tanaman yang lebih tinggi dan berbeda nyata dengan perlakuan lainnya. 
Tabel 4. Pengaruh Konsentrasi Pupuk Organik Cair Urin Domba terhadap Berat Tajuk Tanaman Pakcoy

\begin{tabular}{cc}
\hline Perlakuan & Bobot Tajuk Tanaman (gram) \\
\hline $0 \mathrm{ml} /$ liter air & $18,20 \mathrm{a}$ \\
$5 \mathrm{ml} /$ liter air & $21,47 \mathrm{~b}$ \\
$10 \mathrm{ml} /$ liter air & $22,00 \mathrm{~b}$ \\
$15 \mathrm{ml} /$ liter air & $19,52 \mathrm{ab}$ \\
$20 \mathrm{ml} /$ liter air & $26,13 \mathrm{c}$
\end{tabular}

Keterangan : angka rata-rata yang diikuti hurup yang sama tidak berbeda nyata menurut Uji DMRT taraf kesalahan $5 \%$

Berat tajuk segar tanaman meliputi batang dan daun yang berarti akumulasi dari hasil fotosintesis dan dipengaruhi oleh ketersediaan unsur hara. Berat segar tajuk juga merupakan gambaran dari fotosintesa selama tanaman melakukan proses pertumbuhan. Urin domba merupakan pupuk organik berbentuk cair. Pupuk organik bukan merupakan pengganti dari keberadaan pupuk anorganik namun berfungsi sebagai komplementer. Hal ini dikarenakan kandungan hara makro yang ada dalam pupuk organik rendah, namun pupuk organik memiliki kelebihan yaitu kaya akan hara mikro yang tidak disediakan pada pupuk anorganik.

Pupuk organik juga mengandung hormon pertumbuhan dari golongan auxin dan giberelin yang mampu memacu pertumbuhan sejak dari kecambah sampai buah [24]. Fungsi kimia pupuk organik adalah sebagai penyediaan hara makro ( $N$,
$\mathrm{P}, \mathrm{K}, \mathrm{Ca}, \mathrm{Mg}$ dan S) dan mikro seperti $\mathrm{Zn}, \mathrm{Cu}$, Mo, Co, B, Mn dan Fe. Meskipun secara kuantitatif pupuk organik sedikit mengandung unsur hara, tetapi pupuk organik mampu meningkatkan kapasitas tukar kation tanah, serta dapat membentuk senyawa kompleks dengan ion logam seperti $\mathrm{Al}$, Fe dan $\mathrm{Mn}$ sehingga logam tersebut tidak meracuni tanaman [25]. Kondisi ini tidak dimiliki oleh pupuk anorganik. Pemberian pupuk organik, unsur hara yang tersedia dapat diserap tanaman dengan baik, karena itulah pertumbuhan daun menjadi lebih lebar dan fotosintesis terjadi lebih banyak. Hasil fotosintesis digunakan untuk membuat sel-sel batang, daun dan akar sehingga mempengaruhi bobot tajuk tanaman pakcoy [26].

\section{KESIMPULAN}


Urin domba berpengaruh nyata terhadap tanaman pakcoy pada sistem sumbu. Konsentrasi urin domba $20 \mathrm{ml} /$ liter air menghasilkan tinggi tanaman dan jumlah daun tertinggi yang tertinggi masing-masing , berbeda nyata dengan tanpa urin domba namun berbeda tidak nyata dengan perlakuan urin domba lainnya. Konsentrasi urin domba $20 \mathrm{ml} /$ liter air menghasilkan bobot basah tanaman tertinggi dan berbeda nyata dengan perlakuan lainnya kecuali dengan perlakuan konsentrasi urin domba $10 \mathrm{ml} /$ liter air.

\section{DAFTAR PUSTAKA}

Andriani, V. dan Habibah, R. N. 2019. Penambahan Konsentrasi Fe EDTA pada Nutrisi Ab Mix Terhadap Pertumbuhan dan Produksi Tanaman Pakchoy (Brassica Rapa L.) Sistem Hidroponik Nutrient Film Technique (NFT). Prosiding Seminar Nasional Hayati, 7(1), 159-163.

Purbajanti, E.D., Slamet, W., dan Kusmiyati, F. 2017. Hydroponic: Bertanam Tanpa Tanah. Edisi I. Semarang: EF Press Digimedia.

Siregar, J., S. Triyono, dan D. Suhandy. 2015. Pengujian Beberapa Nutrisi Hidroponik Pada Selada (Lactuca Sativa L.) dengan Teknologi Hidroponik Sistem Terapung (THST) Termodifikasi. Teknik Pertanian, $4(2): 65-72$.
Susilawati. 2019. Dasar-Dasar Bertanam Secara Hidroponik. Palembang: Universitas Sriwijaya.

Swastika, S., Yulfida, A., dan Sumitro, Y. 2017. Budi Daya Sayuran Hidroponik. Cet. ke-1. Pekanbaru: Balai Pengkajian Teknologi Pertanian.

Sastro, Y., dan Rokhmah, N.A. 2016. Hidroponik Sayuran di Perkotaan. Jakarta. Balai Pengkajian Teknologi Pertanian (BPTP) Jakarta.

Marginingsih, R.S. 2018. Pengaruh Substitusi Pupuk Organik Cair pada Nutrisi AB Mix terhadap Pertumbuhan Caisim (Brassica Juncea L.) Pada Hidroponik Drip Irrigation System. Jurnal Biologi dan Pembelajarannya, 5 (1): 44-51.

Fahmi, Z., Suryani., dan Siti, M.S. 2020. Pengaruh Penggunaan Pupuk Cair Organik (POC) Bonggol Pisang Terhadap Produksi Tanaman Caisim (Brassica juncea L.) Sistem Wick. Jurnal IImiah Respati, 11 (2): 140-147.

Alvi, B., Ariyanti, M., dan Maxiselly, Y. 2018. Pemanfaatan Beberapa Jenis Urin Ternak Sebagai Pupuk Organik Cair Dengan Konsentrasi Yang Berbeda Pada Tanaman Kelapa Sawit (Elaeis guineensis jacq.) di pembibitan utama. Kultivasi, 17(2): 622-627.

Sitorus, M.R., Irmansyah, T. dan Ezra, F. 2015. Respons Pertumbuhan Bibit Setek Tanaman Buah Naga Merah (Hylocereus costaricencis Web) Britton \& Ross) 
Terhadap Pemberian Auksin Alami dengan Berbagai Tingkat Konsentrasi. Jurnal Agroekoteknologi, 3 (4): 15571565.

Yanto, S.E. 2017. Pengujian Pupuk Organik Cair Urine Domba Dengan Biochar Cangkang Biji Kemiri Pada Tanaman Kedelai (Glycine Max L.). Skripsi. Program Studi Agroteknologi, Fakultas Pertanian, Universitas Medan Area, Medan.

Parmila, P., Purba, J. H., dan Suprami, L. (2019). Pengaruh Dosis Petroganik dan Kalium terhadap Pertumbuhan dan Hasil Semangka (Citrulus vulgaris SCARD). Agro Bali: Agricultural Journal, $2(1): 37-45$.

Indrawaty dan Veronika. 2016. Pengaruh Penggunaan Urin Sebagai Sumber Nitrogen Terhadap Bentuk Fisik dan Unsur Hara Kompos Feses Sapi. Skripsi. Program Studi Peternakan Fakultas Peternakan. Universitas Jambi. Jambi.

Riwandi., Prasetyo., Hasanudin., I, dan Cahyadinata. 2017. Kesuburan Tanah dan Pemupukan. Yayasan Sahabat Alam Rafflesia. Bengkulu

Irwan, AW., Wahyudin, A., dan Farida. 2005. Pengaruh Dosis Kascing dan Bioaktivator Terhadap Pertumbuhan dan Hasil Tanaman Sawi (Brassica juncea L.) Yang Dibudidayakan Secara Organik, Jurnal Kultivasi, 4 (2) : 136 140.
Rai, I.N. 2018. Dasar-Dasar Agronomi. Fakultas Pertanian, Universitas Udayana, Bali. Penerbit Pelawasari.

Wahyudin, A. - T. Nurmala, dan R. D. Rahmawati. 2015. Pengaruh dosis pupuk fosfor dan pupuk organik cair terhadap pertumbuhan dan hasil kacang hijau (Vigna radiata L.) pada ultisol Jatinangor. Jurnal Kultivasi, 14 (2): 16-22.

Simanjuntak, J., H. Hanum, dan A. Rauf. 2015. Ketersediaan Hara Fosfor Dan Logam Berat Kadmium Pada Tanah Ultisol Akibat Pemberian Fosfor Alam dan Pupuk Kandang Kambing Serta Pengaruhnya Terhadap Pertumbuhan Dan Produksi Tanaman Jagung (Zea mays L.). J. Agroekoteknologi, 3 (2) : 499-506.

Wibowo, S. dan Asriyanti, S. A. 2013. Aplikasi hidroponik NFT pada budidaya pakcoy: jurnal penelitian pertanian terapan, 13 (3): 159-167.

Dominiko, T.A., Setyobudi, L. dan Herlina, N. 2018. Respon Tanaman Pakcoy (Brassica rapachinensis) Terhadap Penggunaan Pupuk Kascing dan Biourin Kambing. Jurnal Produksi Tanaman. Malang (ID): Universitas Brawijya. 6 (1). Harjadi. 1991. Pengantar Agronomi. PT Gramedia Pustaka Utama. Jakarta.

Sitompul, S.M. dan B. Guritno. 1995. Analisis Pertumbuhan Tanaman. UGM-Press. Yogyakarta. 
Jurnal IImiah Respati

Sarief, E. S. 1986. Kesuburan dan

Pemupukan Tanah Pertanian. Pustaka

Buana. Bandung.

Purba, J.H., Wahyuni, P.S., dan Febryan, I.

2019. Kajian Pemberian Pupuk Kandang Ayam Pedaging dan Pupuk Hayati terhadap Pertumbuhan dan Hasil Petsai (Brassica chinensis L.). Agro Bali: Agricultural Journal, 2 (2): 77-88.
Margaretha, S., Yafizham, K.F. Hidayat., dan A. Karyanto. 2015. Pengaruh Kombinasi Dosis Pupuk Anorganik Dan Pupuk Slurry Cair Terhadap Pertumbuhan Dan Produksi Tanaman Kacang Hijau (Phaseolus radiatus L.). J. Agrotek Tropika, 3 (1): 18-23.

Syekhfani. 2000. Arti Penting Bahan Organik Bagi Kesuburan Tanah. Jurnal Penelitian Pup uk Organik. 